\title{
口蓋原発悪性黒色腫由来の初代培養細胞の性状について
}

\author{
吉川文弘・墨 哲 郎・大西徽郎 \\ 岩井聡一・作田正義
}

\section{Character of primary culture cells derived from oral malignant melanoma}

\author{
Fumihiro Yoshikawa - Tetsurou Sumi - Tetsuo Ohnishi \\ Souichi IwaI - Masayoshi SAKUdA
}

\begin{abstract}
Establishment of human cultured cell line derived from metastatic lymph node of malignant melanoma originating in the hard palate is reported. It's cell line was named HM 162 and was nearly spindle shaped. The cells were melanotic in the early stage but became amelanotic in the late stage of the culture. But the cell produced melanin along with $0.1 \%$ of L-DOPA for several hours.

HM 162 cells secreted a factor into the culture medium which stimulated their own growth.

Such a factor may be contributed, to some extent to the high malignancy of malignant melanoma.
\end{abstract}

Key words: malignant melanoma (悪性黑色腫), primary culture cell (初代培差細胞), growth factor（増殖因子）

緒 言

悪性黑色腫は, メラノサイトに由来する悪性腫痬であ る。周囲組織への強い浸潤性增殖能と他臓器への高い転 移巣形成能を有しているために, 最も悪性度の高い腫瘍 の 1 つされている1,2)。特にその高転移能は, 臨床の 場に拈いて治療を困難にしている大きな因子である.

今回, 筆者らはとト悪性黑色腫細胞を頸部りンパ節転 移巣より分離し，株細胞化することに成功したので（以 下 HM 162 細胞と記す), 若干の知見とともに報告す る.

\section{実験材料および方法}

\section{1. 患 者}

大阪大学䑦学部口腔外科学第 2 講座

（主任：作田正義教授）

Second Depariment of Oral Surgery, Faculty of

Dentistry, Osaka University (Chief: Prof. Ma-

sayoshi Sakuda)

受付日: 平成 3 年 6 月 24 日

\section{6 歳 男性}

右側硬口蓋部の刺激痛を主訴として昭和63年 7 月 に当科に来院した。原発紧は右側硬口蓋部（ 6 ～3| 部） であった７月日日に原発腫瘍切除術（上買骨部分切除 術),および右側全頸部郭清術を施行した。病理組織䛦 断の結果は悪性黑色腫であり, 右側頸部りンパ節（レベ ル I， II) に転移が認められた。術後に化学療法 (DAV 療法)を2クール行い, 以後継続的に OK-432を投与 しつつ経過観察を行った。

平成元年 5 月曰日の定期観察の際に左側靧下リンパ節 に転䔟と思われる腫瘤を認めたため，6月ロ日に左側全 頸部郭清術を施行した。術後に化学療法 (DAV 療法) を2クール行った，その後も経過観察を継続しつつ 3 4 か月扣きに化学療法 (DAV 療法) を施行していたと ころ,上顎㧍よび頸部には再発を認めなかったが, 全身に 広範囲に転移をきたし, 平成 2 年 4 月回日に死亡した。

\section{2. 腫瘍材料}

初回時扣よび 2 度目の手術の際の頸部りンパ節で転移 单と考えられるもの, すなわち黒い着色の認められるり ンパ節を初代培着の材料として用いたが，2 度目の手術 の際のリンパ節において初代培差に成功したので，林細 胞化を試みた。 


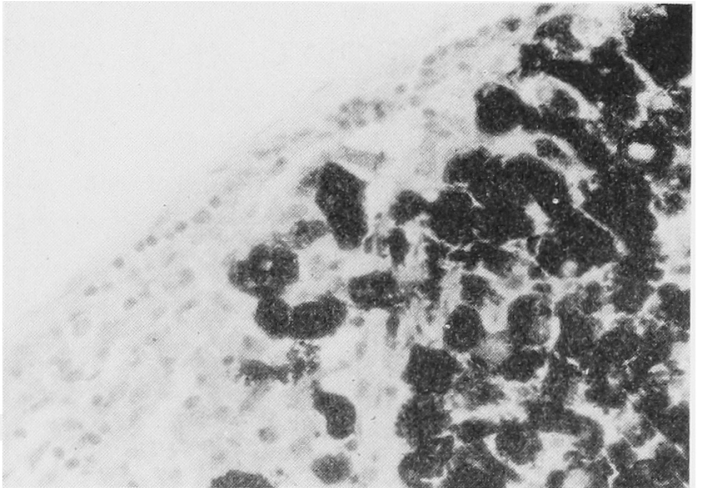

写真 1 転移リンパ節の組織像 (H-E 染色, 200 倍).

なお，残余の組織片より悪性黒色腫の転移巣であるこ とを確認している（写真 1 ）。

\section{3. 培養方法}

1) 培差液

Dulbecco MEM 培地 (DMEM - Sigma 社) 飞牛胎 児血清（FCS ・ GIBCO 社）を10\%添加したものを用い た.

\section{2）培養方法}

Explant-outgrowth 法3)を用いて腫瘍細胞を遊出させ た、すなわら，得られた転移りンパ節をりン酸緩衝液 (PBS(-)) 中で洗浄後に $3 \sim 4 \mathrm{~mm}$ 角の大きさに細切 りし, $90 \mathrm{~mm}$ プラスチックディッシニ (Corning 社) の 底面に静置し，上記培養液㕝 1 滴滴下した後に $5 \%$ $\mathrm{CO}_{2} \cdot 37^{\circ} \mathrm{C}$ のインキュベーター内に静置した。 24 時間 後に $12 \mathrm{ml}$ の上記培着液を加光, さらに 3 週間静 置 培 養し，尰汮細胞か十分に遊出した後に継代培羡に移行し た.すなわち $0.05 \%$ ナリプシン（阪大微生物研究所） +0.02\% EDTA (石津製薬) を含む PBS (一) を用い て細胞をプラスチックディッシュの底面より遊離させた 後に，DMEM+10\% FCS を用いて継代培盖を行った。

\section{3) 培差細胞の単離}

継代培盖に移行してから約 7 か月後, 培養15代目の細 胞に対して 2 層軟寒天培盖法文を用いてクローニングを 行った。すなわち， $35 \mathrm{~mm}$ プラスチックディッシュに $0.6 \%$ 寒天を含む DMEM $2 \mathrm{ml}$ を加光，固まった後 に0. $3 \%$ の寒天を含它 DMEM $1 \mathrm{ml}$ 中に $10^{3}$ 個の腫瘍細 胞を㗭濁させたものを重層させて培養した，2〜3週後 に形成されたコロニーをパスッールピペットを用いて分 離し，プラスチックディッシュ上で培養し增殖させた。

4. 培妻上清 (Conditioned Medium - CM) の採取 培養增殖させた $\mathrm{HM} 162$ 細胞 (90 mm ディッシュ)

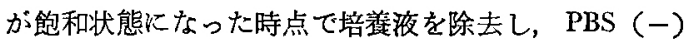
にて洗浄した後に血清無添加の DMEM を $12 \mathrm{~m} l$ 加
え，96時間培荃した培養上清を CM として用いた。

\section{DNA 合成の測定}

${ }^{3} \mathrm{H}$ - サイミジンの取り込みを指標として DNA 合成

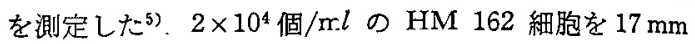
ディッシュ（24穴）に接種し，48時間培症した。 その後 に, 種々の濃度の CM を含んだ血清無添加の DMEM に培地を交換し, 同時に $1 \mu \mathrm{Ci}$ の ${ }^{3} \mathrm{H}-$ サイミジンを 加え 8 時間培養した。培地を除去した後に $4^{\circ} \mathrm{C} の$ PBS （一）およびトリクロ口酢酸で洗浄し，4 $\mathrm{C}$ のメター ルて脱水した後に $1 \mathrm{~N} \mathrm{VaOH}$ を $1 \mathrm{~m} l$ 加えて溶解し たそそのらちの $0.4 \mathrm{ml}$ にシンチレーション液を加え, 液体シンチレーションスペクトロメーター (LBK) K より放射活性を測定した．さらに Bradford の方法に準 して各ディッシュのタンパク量を測定し6), 各ディッシ

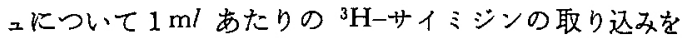
算定して DNA 合成の指標とした。な和 1 グループは 6 ディッシュの平均とした。

結果

\section{1. 初代細胞の增殖状態}

初代培羕を開始して14日目ごろから，組織片の周囲へ の細胞の遊出が認められた。

\section{2. 継代培養への移行}

初代培盖後27日目に 1 回目の継代培養を行った，細胞 形態はほぼ紡錘形であったが，かなり不整であった。以 後約 2 週間扣をに継代培着を行った。

\section{3. クローニング}

12 代目の継代培善細胞に対して 2 㬝軟寒天培責法を用 いてクローニングを行ったところ，4週間後に約 $30 \%$ の 細胞がコロニーを形成した。 コロニーは白色で周囲に細 胞の浸潤が認められた（写真２）．コロニーをパスッー ルピペットで分離してさらに継代培養を行ったが，クロ ーニング後の細胞は紡錘形であり，ほほ沟一な形態を示 していた（写真了）.

\section{4. メラニン産生態}

転移リンパ節より摘出した培養材料は黒色を呈し, メ ラニンの存在を示していたまま，組織片から遊出した 初代細胞もメラニンを含有し著明な黒色を呈していた。

しかしながら継代培盖をくり返すうちにメラニンを含ま ない無色の細胞が出現し，しだいにその比率が増加して いった．軟寒天中で形成されたコロニーはすべて白色で

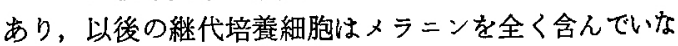
かった。

初代細胞からクローニング後の継代培盖細胞にいたる まで培荃液中には，メラニンの放出は全く認められなか った。しかしながらクローニング後の継代培㟤細胞の培 羡液中に0.1\%の L-DOPA を添加すると数時間内にメ ラニンを旺盛に産生した。 


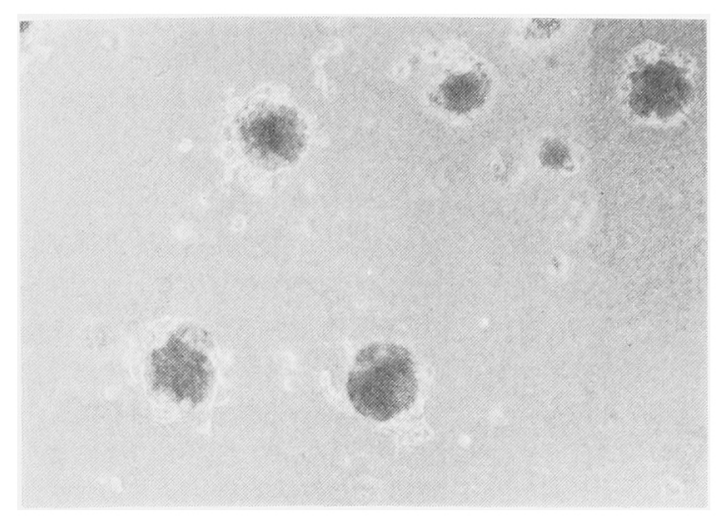

写真 22 層軟寒天培盖法により形成された HM 162 細胞のコロ = ( 40 倍).

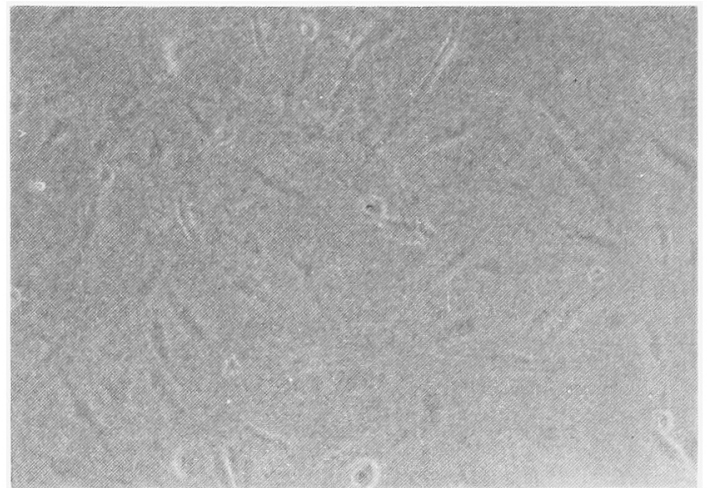

写真 3 HM 162 細胞の位相差頙微鏡像 (400倍).

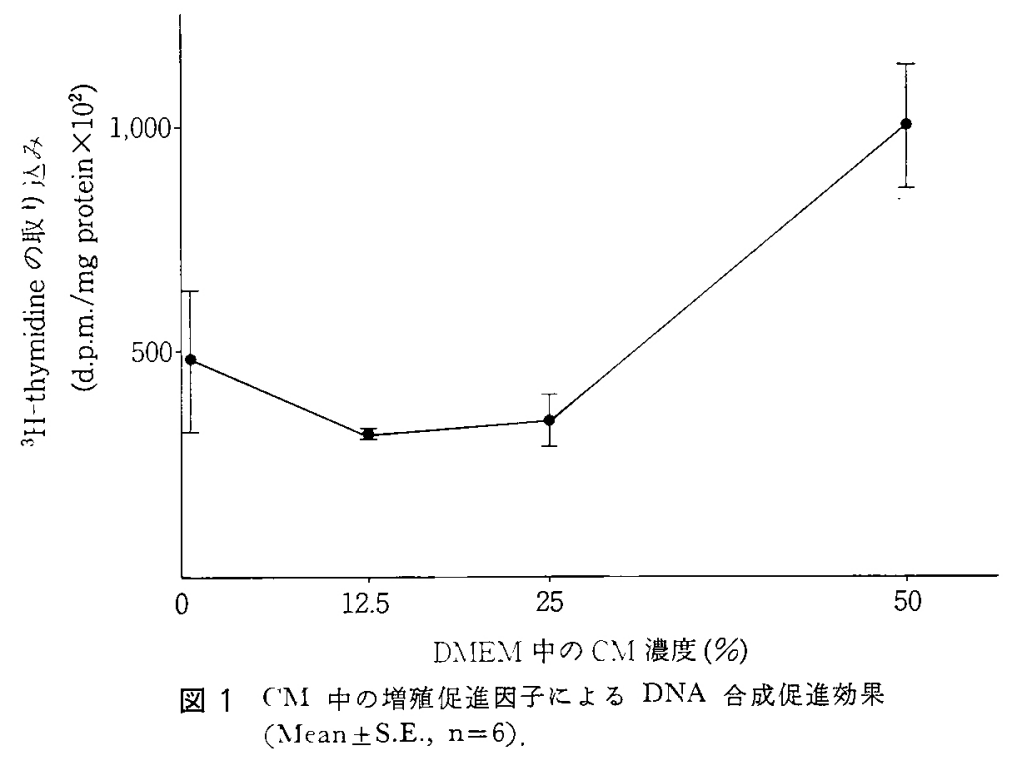

\section{HM 162 細胞の培養上清中に存在する DNA 合} 成促進因子について

CMI 中 HM 162 細胞に対する DNA 合成促進因 子が存在するか否か炕ついて検討した。すなおち，飽和 状態になる直前の HM 162 細胞の培着液を除去し， 0 〜 50\%の各段階の CM を含む血清無添加の DMEN を加え，HM 162 細胞自身の DNA 合成の状態を検討 したところ，50\% CM の添加によって明確な DNA 合 成促進効果が認められた。すなわち HM 162 細胞は自 己分泌性に自己の細胞の增殖を促進させるような因子を 放出していることか゚あきらかとなった（図1）。

\section{考察}

口腔領域に発生する悪性腫場のなかで, 覀性黑色腫は 周囲組織への強い浸潤性増殖能と他の葴器への高い転移 巣形成能を有しているために最す悪性度の高い腫瘍の 1 つとされており，扁平上皮癌などに比して予後はかなり 不良である.

その高い悪性度に関与している因子を解明するために 多大な努力がなされてきたが，いまだに多くの不明な点 が残されている. 
このよらなメカーズムを解明する1つの方法として腫 瘍細胞を in vitroにおいて培差細胞化し，ての有してい る特性を調べる方法がある。実際，悪性黑色腫細胞を培 着細胞化した報告はいくつかあるが，形態面での検査が 中心に行われていた7) しかしながら，培差細胞化され た細胞は生化学的因子の検索に抏いても有効である。特 に腫瘍細胞の放出している因子などを検索する手法とし て有力である。そこで筆者らは培差細胞化した悪性黑色 腫 (HM 162 細胞) を用いて生化学的検索を行らことを 目的として悪性黑色腫細胞の培着細胞化を試みた。

一般に恶性黑色腫由来の細胞においては, メラノソー 么の数と細胞增殖との間には反比例の傾向がある ${ }^{8)}$ とさ れており, 口腔悪性黒色腫の頸部転移巣由来の継代培盖 細胞においても同様の報告がなされている 細胞の場合も，培着開始直俊には色素性であったが，増 殖が活発化すると同時に黑化の程度が減少し, クローン 化の後には無色素性となった。しかしながら，っローン 化の後の無色素性になった HNI 162 細胞に対し， 0.1 \%の L-DOPA を培差液中に源加すると数時間内にメラ ニン色素を旺盛に産生した。すなおち HM 162 細胞が 無色素性となっても DOPA オキシダービは有している ものと思われる。

悪性腫場細胞は自己分泌能により自己の增殖に必要な 因子を産出していることが知られており ${ }^{10)}$, そのため培 晸時に血清が存在しなくても增殖寸ることが可能である とされている，著者の 1 人である吉川もウサギ $\mathrm{VX}_{2}$ 癌 細胞の放出する自己增殖因子について報告している5

悪性黒色腫は非常に強い浸潤性增殖能と旺盛な転移巣 形成能を有している。したがって，覀性黑色腫由来の HM 162 細胞にもそれらの形質を支える何らかの生化 学的要因を有している可能性が考えられたので, その可 能性について检討を加えた。 その結果, 先に示した結果 のごとく，50\% CM の泒加によってあきらかな DNA 合成促進効果が認められた。すなおち HM 162 細胞は 自己分泌性に自己增殖促進因子を放出していることがあ きらかとなった。腫瘍細胞自身が自己增殖促進因子を放 出していることによって, 覀性腫瘍の原発巣に拈汁る周 囲への浸潤性增殖がより効果的になされるということは 十分に可能性があると思われる。亦た原発巣から離脱し た腫瘍細胞が摽的缄器に着床した後, 転移单を形成寸る 過程においても自己增殖促進因子は有効に働くものと考 えられる. 以上のような点より，HM 162 細胞の放出 している自己增殖促進因子は，悪性黑色腫が生体内にお いて発現する強い浸潤性增殖能と高い転移形成能を形成 する1つの要因である可能性が考えられた。 それに加え て, その他にも運動能促進因子や宿主免疫能阻害因子な どの形質発現促進因子の存在の可能性が考えられる.今 後, これらの因子の模䕀を行い，その性状をあきらかに することによって悪性黑色腫の有している高い悪性度を
成立せしめているメカニズムの解明の可能性も考えられ る.

結語

今回われわれは口圔原発悪性黑色腫の頸部りン八節転 移巣より腫瘍細胞を分離し，培羕細胞化することに成功 した。細胞の形態はほぼ紡錘形であり，培養初期には細 胞内にメラニンを含有していたがクローニング後には細 胞内のメラーンは消失した。同細胞は培差上清中に自ら の DNA 合成を促進する因子を放出していた。そのよう な因子は自らの増殖に対して効果的に作用することが想 像され，悪性黑色腫の有する高い悪性度に貢献している 可能性が考えられる.

本論文の要旨は, 第35回日本口腔外科学会総会(岡 山）において発表した。

\section{引用文 献}

1) Ronald, P.R., Loren, E.G., et al.: Primary malignant melanoma of the oral cavity. Cancer 55: 1543-1551 1985.

2) Shafer, W.G., Hine, M.K., et al.: A textbook of oral pathology. 4th Ed, W.B, Saunders Co, Philadelphia, 1983, p 133-137.

3) Jensen, F.C., Gwatkin, R.B.L., et al.: A simple method which allows simultaneous isolation of specific types of cells. Exp Cell Res 34: 440-447 1964.

4) Shirasuna, K., Watatani, K., et al. . Isolation and characterization of different clones including myoepithelial-like variants from a clonal neoplastic epithelial duct cell line of human salivary gland origin. Cancer Res 46 : 1418-14261986.

5) 吉川文弘： $\mathrm{VX}_{2}$ 癌細胞の連動性に関する稩胞 生物学的扣上び生化学的研究. 阪大㦀誌 30 : 87-109 1985.

6) Bradford, M.M.: A rapid and sensitive method for sensitive method for the quantification of microgram quantities of protein utilizing the principle of protein-dye binding. Anal Biochem 72: 248-254 1976.

7) 田中信幸, 結城勝彦, 他 : 口腔恶性黑色腫由来

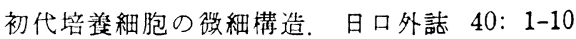
1991.

8) Hu, F., Mah, K., et al.. Electoron microscopic and cytochemical observation of the theopyllin and melanocyte-stimulating hormone effects on melanoma cells in culture. Cancer Res 42: 2786-2791 1982.

9）乾 真澄可, 田川俊郎, 他：口蓋覀性黑色腫原 


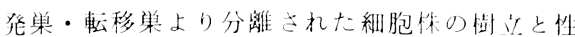
状。口科誌 38：121-1301989.

10）米田俊之，北村昌也，他：睡瑒增殖の調節嘰

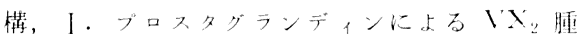
瘍細胞の增殖促進作用。日口外誌 28 ： 1425 14321982. 